LWSA

PAPER - OPEN ACCESS

\title{
Analisis Model SIPABIO dalam Pemetaan Potensi Konflik Menjelang Pemilu Legslatif Tahun 2019 di Kabupaten Aceh
}

\author{
Author : Cut Maya Aprita Sari \\ DOI $\quad: 10.32734 /$ lwsa.v1i2.214 \\ Electronic ISSN : :2654-7066 \\ Print ISSN :2654-7058
}

Volume 1 Issue 2 - 2018 TALENTA Conference Series: Local Wisdom, Social and Arts

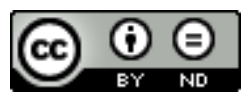

This work is licensed under a Creative Commons Attribution-NoDerivatives 4.0 International License.

Published under licence by TALENTA Publisher, Universitas Sumatera Utara
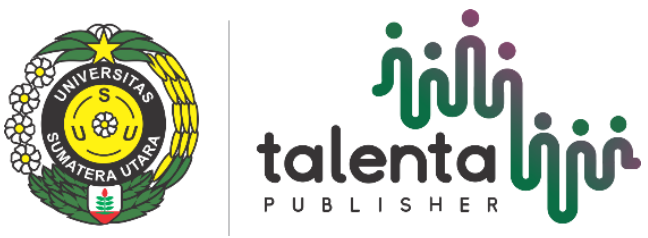


\title{
ن talenta \\ Available online at https://talentaconfseries.usu.ac.id

\section{Analisis Model SIPABIO dalam Pemetaan Potensi Konflik Menjelang Pemilu Legslatif Tahun 2019 di Kabupaten Aceh}

\author{
Cut Maya Aprita Sari ${ }^{\mathrm{a}^{*},}$ Effendi Hasan ${ }^{\mathrm{a}}$, Ubaidulla ${ }^{\mathrm{a}}$, Faradilla Fadlia ${ }^{\mathrm{a}}$ Ardiansyah $^{\mathrm{a}}$ \\ ${ }^{a}$ Fakultas Ilmu Sosial dan Ilmu Politik, Universitas Syiah Kuala, Banda Aceh, Indonesia \\ cutmayaapritasari@unsyiah.ac.id
}

\begin{abstract}
Kabupaten Aceh Tenggara merupakan daerah yang sering luput dari pemantauan konflik pemilu. Hal ini terlihat dari hasil pemantauan pemilu oleh beberapa lembaga yang menyatakan bahwa Aceh Tenggara tidak termasuk kedalam daerah rawan konflik. Sebaliknya, pemberitaan disejumlah media masa menuliskan konflik pemilu di Aceh Tenggara terjadi mulai dari tahun 20062017.Penelitian ini bertujuan untuk memetakan konflik pemilu yang terjadi di Aceh tenggara sepanjang tahun 2006-2017. Hasil pemetaan konflik ini dipergunakan untuk memproyeksikan potensi konflik yang mungkin muncul pada pemilu legislatif 2019. Penelitian ini pula menggunakan metode kualitatif dengan memantau media masa baik cetak dan elektronik serta mengunjungi langsung Kabupaten Aceh Tenggara untuk melakukan wawancara dengan pihak terkait. Data yang didapatkan dianalisis dengan menggunakan model SIPABIO (Source, Issue Parties, Attitude, Behavior, Intervention, and Outcome). Hasil dari penelitian ini menunjukkan bahwa Aceh Tenggara merupakan daerah berpotensi konflik. Berdasarkan hasil pemetaan konflik model SIPABIO, dapat disimpulkan bahwa terdapat tiga pihak utama yang menjadi sumber konflik yaitu KIP Aceh Tenggara, Kepolisian, dan simpatisan masing-masing calon. Ketiganya dominan menunjukkan sikap non coercive action dengan melakukan intimidasi, money politic, dan demonstrasi. Meskipun potensi konflik relatif kecil, kewaspadaan dan tindakan preventif harus terus diupayakan untuk meminimalisir terjadinya konflik pada pemilu legislatif yang akan datang.
\end{abstract}

\section{Pendahuluan}

Situasi yang konfliktual masih mewarnai pesta demokrasi di Provinsi Aceh. Sebagai daerah pasca konflik, potensi kekerasan politik masih terus muncul terutama menjelang diadakannya pemilihan umum (Pemilu) baik pemilu legislatif maupun pilkada. Berbagai laporan pemantauan pemilu dari tahun ketahun menunjukkan bahwa Provinsi Aceh selalu mengalami berbagai kasus pelanggaran pemilu. Kasus-kasus ini pada akhirnya berimplikasi terhadap konflik pemilu dan mengganggu stabilitas keamanan.

Pada dasarnya, baik pemilu legislatif maupun pilkada menyimpan potensi konflik yang hampir sama. Keduanya saling berhubungan dalam konteks relasi elit-elit politik yang bertarung. Hasil pemantauan pemilu yang dilakukan oleh beberapa lembaga menunjukkan bahwa eskalasi konflik dan pelanggaran pemilu tertinggi berada di daerah Aceh Pidie, Aceh Utara, Aceh Tengah, dan Aceh Selatan [1];[2];[3];[4]. Berdasarakan pemantauan tersebut, Aceh Tenggara tidak termasuk kedalam wilayah yang mengalami konflik pemilu. Hal ini berbanding terbalik dengan pemberitaan di beberapa media massa yang menuliskan bahwa sering terjadi tindak kekerasan pada pelaksanaan pemilu di Aceh Tenggara.

Sejumlah data memperlihatkan bahwa Aceh Tenggara mengalami kekerasan politik baik pada pelaksanaan pilkada tahun 2006,2012 dan 2017maupun pada pelaksanaan pilkada tahun 2009 dan 2014. Beberapa kasus pelanggaran 
pemilu yang terjadi meliputi pengrusakan posko pemenangan, pengrusakan atribut kampanye, intimidasi, pembakaran, maupun orasi yang memprovokasi [4]; [2]. Berdasarkan data diatas maka kemungkinan besar Pada perhelatan pemilu legislatif di Aceh tahun 2019, Aceh Tenggara memiliki potensi konflik yang tinggi. Maka rumusan permasalahan yang diajukan dalam penelitian ini adalah "bagaimana pemetaan potensi konflik pada pemilu legistalif tahun 2019 di Kabupaten Aceh Tenggara?", Sedangkan tujuan dari penelitian ini yaitu untuk mendapatkan hasil pemetaan konflik yang dapat dipergunakan untuk memproyeksikan potensi-potensi konflik yang mungkin muncul. Sehingga dapat dirumuskan tindakan preventif untuk meminimalisir terjadinya konflik di masa mendatang.

Pemetaan konflik dalam penelitian ini menggunakan model SIPABIO (Source, Issue Parties, Attitude, Behavior, Intervention, and Outcome) sebagai alat analisis [5]. Awalnya, model ini dikembangkan untuk menganalisis konflikkonflik social. Tetapi ternyata kami menemukan suatu keterbaruan dalam penggunaan model ini. Dimana SIPABIO bukan hanya mampu menganalisis konflik social, tetapi juga mampu untuk menganalisis konflik politik.Penelitian mengenai konflik pemilu di Aceh telah banyak dilakukan. Namun kami belum menemukan penelitian terdahulu yang berfokus pada pemetaan potensi konflik di Aceh Tenggara dengan menggunakan model SIPABIO sebagai alat analisis. Oleh karena itu, penelitian ini menjadi menarik untuk diteliti

\section{Bahan dan metode}

Lokasi penelitian

Penelitian ini dilakukan di Kabupaten Aceh Tenggara, Provinsi Aceh. Alas an pemilihan lokasi ini adalah karena Aceh Tenggara memiliki keunikan tersendiri disbanding dengan kabupaten lain yang ada di Provinsi Aceh. Kabupaten ini memiliki 16 kecamatan dengan komposisi penduduk yang terdiri dari 11 etnis yang berbeda yaitu Alas, Gayo, Batak, Pakpak, Singkil, Mandailing, Aceh, Karo, Padang, Jawa, dan Nias. Wilayah ini juga memiliki keberagaman keyakinan yang didominasi oleh Islam dan Kristen. Keberagaman suku dan keyakinan melahirkan kondisi masyarakat yang sangat beragam dan bervariasi. Keberagaman ini menimbulkan kepentingan politik yang berbeda-beda sehingga menyimpan potensi konflik yang cukup tinggi.

\section{Metode}

Penelitian ini telah dilaksanakan sejak pertengahan bulan Mei sampai dengan bulan Agustus 2017. Pengumpulan data dilakukan secara kualitatif dengan memantau media masa baik cetak dan elektronik serta mengunjungi langsung Kabupaten Aceh Tenggara sebagai objek dari penelitian. Kunjungan langsung dilakukan guna mencari informasi yang valid berkaitan dengan isu konflik pemilu yang telah terjadi sebelumnya.Metode penelitian yang digunakan adalah metode kualitatif menggunakan wawancara informal dengan berpandukan kepada daftar pertanyaan terbuka.Data yang telah didapatkan selanjutnya melalui proses maping konflik. Tahapan maping dilakukan dengan mengklasifikasikan data-data yang diperoleh dan mengelompokkannya berdasarkan tahun konflik. Tahap selanjutnya yaitu analisis eskalasi konflik dengan menggunakan maping yang telah tersusun sebelum nya. Setiap maping data yang telah terklasifikasi menurut tahun dan pola konflik dianalisis dengan tahapan SIPABIO. Hasil analisis yang didapatkan berupa pemetaan potensi konflik yang mungkin terjadi di masa mendatang. Melalui pemetaan tersebut maka dapat disusun rekomendasi berupa tindakan preventif untuk menekan konflik.

\section{Hasil}

Pelaksanaan pemilu pasca konflik menjadi urgensi bagi pemerintahan Aceh. Dalam hal ini pemilu diharapkan menjadi instrument untuk mengelola kepentingan politik dikalangan elit-elit politik. Namun demikian, harapan ini tentu tidak sepenuhnya terwujud. Pemilu Aceh selalu mencatat berbagai pelanggaran pemilu yang berpotensi menimbulkan konflik bagi pilkada mendatang. Hasil pemantauan beberapa media masa menunjukkan bahwa Aceh memiliki potensi konflik pemilu yang tinggi. Tahun 2014, terdapat 38 kasus besar terkait dengan jenis pelanggaran dan kekerasan pemilu[6] yang yang dapat dilihat pada tabel dibawah ini: 
Tabel 1. Jenis Pelanggaran dan Kekerasan Pada Pemilu Aceh Tahun 2014

\begin{tabular}{lc}
\hline Jenis Kekerasan & Jumlah \\
\hline Penganiayaan & 6 \\
Pembakaran Mobil & 5 \\
Intimidasi & 3 \\
Pembunuhan & 3 \\
Penculikan & 2 \\
Perusakan Posko & 1 \\
Penembakan & 1 \\
Pengrusakan alat peraga kampanye & 13 \\
Pengancaman & 1 \\
Pemalsuan Surat dan Dokumen & 1 \\
Kampanye diluar jadwal & 2 \\
\hline
\end{tabular}

LSM Kontras ${ }^{[1]}$ mencatat bahwa sepanjang bulan januari sampai april 2014, kekerasan politik menjelang pemilu meningkat di seluruh Aceh dengan jenis tindakan kekerasan berupa pengrusakan (36 kasus), intimidasi (6 kasus), Penembangkan (5 Kasus), bentrokan (1 Kasus), penculikan (2 kasus) dan penganiayaan (17 kasus). Dalam rentang waktu ini pula tercatat 6 orang tewas, 27 luka penganiayaan, puluhan harta benda termasuk atribut partai rusak dan dibakar.

Kabupaten Aceh Tenggara merupakan bagian dari Provinsi Aceh yang sering luput dari pemantauan konflik pemilu. Beberapa lembaga pemantau pemilu menyebutkan bahwa eskalasi konflik dan pelanggaran pemilu tertinggi berada di daerah Aceh Pidie, Aceh Utara, Aceh Tengah, dan Aceh Selatan ${ }^{[1] ;[2] ;[3] ;[4]}$ dan Aceh Tenggara tidak termasuk didalamnya.

Melalui penelitian ini kami justru mendapatkan hasil sebaliknya. Aceh Tenggara merupakan daerah berpotensi konflik terkait dengan munculnya beberapa kasus pelanggaran pemilu di sepanjang tahun 2006-2017. Meskipun potensi tersebut relatif kecil, kewaspadaan dan tindakan preventif harus terus diupayakan untuk meminimalisir terjadinya konflik pada pemilu legislatif yang akan datang. Kondisi demografis penduduk Aceh Tenggara dengan keberagaman suku dan agama menyebabkan terkotak-kotaknya kepentingan politik para elit dan masyarakat. Perbedaan kepentingan ini menjadi determinan terjadinya pelanggaran pemilu yang berujung kepada konflik. Beberapa data konflik yang kami temukan melalui media massa dan data lapangan dapat dilihat pada tabel dibawah ini:

Tabel 2. Kasus Pelanggaran Dan Konflik Pemilu Aceh Tenggara Tahun 2006-2017

\begin{tabular}{cl}
\hline Tahun & \multicolumn{1}{c}{ Kasus } \\
\hline 2006 & Tuduhan suap terhadap para pemilih yang terjadi dua hari menjelang pemungutan suarayaitu pada tanggal 9 \\
& desember 2006. Beberapa oknum PNS, dan anggota DPRD dituduh melakukan suap kepada para melih di desa Bun- \\
& Bun Alas dan Bun-Bun Indah. Mereka membagikan uang Rp.50.000 kepada masyarakat yang setuju untuk memilih \\
& bupati incumbent Armyn Desky [7]. \\
& Penolakan hasil pilkada yang dilakukan oleh seluruh calon disebabkan oleh tuduhan kepada polisi yang memihak \\
& kepada salah satu calon, adanya intimidasi, dan korupsi anggota KIP dalam pengadaan kotak suara [8] \\
& Gugatan hukum oleh bupati incumbent Armyn Desky dan pertikaian antar lembaga. Semua gugatan yang \\
& dilayangkan terus berlangsung sampai tahun 2008 namun tidak mengubah hasil pilkada.[2];[9];[10]. \\
& Menjelang Pileg, tanggal 29 september terjadi pembakaran kantor Partai Aceh (Data Lapangan).
\end{tabular}


Pada tanggal 5 Januari kantor daerah tingkat sagoe Partai Aceh yang berlokasi di Lawe Sumur dibakar orang tak dikenal yang diduga simpatisan salah satu parpol [11].

2012 KIP Aceh Tenggara tetap meloloskan Armyn Desky yang merupakan Mantan Narapidana Kasus Tipikor.Hal ini melanggar syarat administratif, kode etik serta merugikan pasangan calon lain. Akhirnya DKPP melalui putusan No.04/KE-DKPP/VII/2012 memecat keanggotaan KIP Aceh Tenggara [12].

2014 Teuku riefky Harsya ketua bapilu partai Demokrat dalam siaran pers sabtu (12/4) memaparkan dugaan pelanggaran pada pemilu legislative di Aceh Tenggara. Menurutnya terdapat kecurangan terstruktur yang melibatkan penyelenggara pemilu dna pemerintah daerah [13].

2016 Demonstrasi dilakukan oleh ribuan pendukung paslon Bupati/Wakil Bupati Rasidin Pinim ke KIP Aceh Tenggara 13 Desember 2016 terkait DPT yang dimanipulasi [14].

2017 Demonstrasi di kantor KIP Aceh Tenggara pada 2 may 2017. Terkait kasus belum dibayarnya honor 2300 anggota TPS di 385 Desa selama dua bulan (Data Lapangan).

Dari tabel diatas dapat dianalisis analisis bahwa konflik di Aceh Tenggara menunjukkan pola yang sama yaitu didominasi oleh pelanggaaran pemilu. Tidak terdapat tindak kekerasan fisik sepanjang tahun 2006-2017. Pada pemilu tahun 2006, kami menemukan Aceh Tenggara sebagai kabupaten yang paling bermasalah terkait hasil pilkada. Keterlambatan penetapan pemenang menimbulkan kericuhan baik antar calon maupun antar simpatisan. Meskipun KIP Provinsi Aceh sudah melakukan intervensi, kasus ini tetap berlarut-larut. Pada Akhirnya Hasanuddin dinyatakan menang, mengalahkan incumbent Armen Desky dengan selisih 2.624 suara.

Ketidakharmonisan hubungan antar faksi elit dan simpatisan terlihat sejak tahun 2006. Sehingga Pilkada yang dilaksanakan di tahun 2006 menunjukkan tingkat konflik yang tinggi. Bahkan menurut hasil wawancara dengan sejumlah masyarakat ditemukan bahwa konflik ini berlanjut ke tingkat desa dimana pendukung Hasanudin dan Armeyn Desky terus berseteru. Kekalahan Desky sebagai incumbent dimanfaatkan oleh pendukung Hasanudin untuk menyingkirkan mereka dari jabatan-jabatan kekuasaaan di tingkat desa.Tabel diatas juga memperlihatkan bahwa eskalasi konflik dari tahun 2016 ke tahun 2017 mengalami penurunan. Meskipun konflik yang terjadi tergolong kecil dibandingkan dengan daerah lain di Aceh, namun hal ini perlu diwaspadai demi mewujudkan pemilu damai dan demokratis.

\section{Pembahasan}

Berdasarkan data-data diatas, maka peneliti melakukan pemetaan konflik dengan menggunakan metode pemetaan yang diadopsi dari model SIPABIO (Source, Issue Parties, Attitude, Behaviour, Intervention, and Outcome) dan dapat dirincikan sebagai berikut [5]:

Menentukan Source (sumber konflik) yaitu mencari sumber-sumber konflik dengan analisis hubungan sosial (analisis konstruksi sosial), nilai-nilai seperti identitas politik, dan dominasi structural (analisis structural positivis dan kritis). Pada Pemilu Aceh Tenggara, sumber konflik berasal dari pihak penyelenggara pemilu yaitu KIP, kepolisian, dan simpatisan. Meskipun Aceh Tenggara merupakan daerah dengan keberagaman yang tinggi, ternyata isu SARA tidak menjadi determinan konflik. Penyelenggara pemilu seperti KIP dan pihak kepolisian Aceh Tenggara dinilai berpihak dan tidak menjalankan tugasnya secara baik sehingga menimbulkan konflik. Selain itu, sumber konflik berasal dari hubungan sosial yang asimetris antara simpatisan antar partai politik. Masing-masing simpatisan memiliki loyaitas yang tinggi terhadap calon yang didukung sehingga melakukan upaya-upaya kekerasan demi menjatuhkan saingannya.

Mengidentifikasi Issues (isu-isu) yang merujuk kepada saling keterkaitan tujuan-tujuan yang tidak sejalan di antara pihak bertikai. Isu ini dikembangkan oleh semua pihak bertikai dan pihak lain yang tidak teridentifikasi tentang sumber-sember konflik.Berkaitan dengan hal ini, terdapat pola isu yang sama di sepanjang terselenggaranya pemilu di Aceh tenggara. Pola tersebut yaitu kampanye hitam dan kecurangan yang saling dituduhkan antar simpatisan partai politik sehingga memunculkan prejudice yang berujung kepada konflik. 
Mengidentifikasi Parties (pihak) berupa pihak yang berkonflik baik pihak konflik utama yang langsung berhubungan dengan kepentingan, pihak sekunder yang tidak secara langsung berhubungan dengan kepentingan, dan pihak tersier yang tidak berhubungan dengan kepentingan konflik. Pihak tersier ini yang sering dijadikan sebagai pihak netral untuk mengintervensi konflik.Pihak utama yang menjadi Aktor dominan dalam konflik ini adalah simpatisan masing-masing calon. Sedangkan Pihak sekunder yang dapat diidentifikasi adalah penyelenggara dan pengawas pemilu yang dalam hal ini adalah KIP Aceh Tenggara. Pihak sekunder ini tidak secara langsung berhubungan dengan kepentingan namun fungsi dan tugasnya yang sering dijalankan dengan tidak sesuai berimplikasi terhadap munculnya konflik. Pihak tersier yang ditemukan dalam konflik pemilu Aceh tenggara Adalah DKPP dan KIP Provinsi Aceh. Pihak ini mampu bersikap netral berpotensi untuk mendesak pihak utama dan sekunder untuk tidak berkonflik.

Menganalisis Attitudes / felling (sikap) yang mempengaruhi pola perilaku konflik. Sikap bisa muncul dalam bentuk yang positif dan negatif bagi konflik. Pada dasarnya, sikap yang mempengaruhi pola prilaku konflik adalah keinginan berkuasa dan penolakan terhadap kemenangan kandidat lain. Dapat dianalisa bahwa ini terjadi karena ketakutan pribadi dan tidak adanya kepercayan diri untuk memenangkan pemilu yang mengakibatkan para calon dan simpatisan cendrung menggunakan cara-cara yang tidak fair untuk memperoleh kemenangan.

Menganalisis Behavior (perilaku / tindakan) berupa aspek tindak sosial dari pihak yang berkonflik, baik muncul dalam bentuk coercive action dan noncoercive action.Dapat dianalisis bahwa pihak yang berkonflik lebih cendrung melakukan noncoercive action. Hal ini ditunjukkan dengan melakukan tindakan kecurangan, intimidasi, dan moneypolitics.

Mengidentifikasi adanya Intervention (campur tangan penyelesaian) yaitu adanya tindakan sosial dari pihak netral yang ditujukan untuk membantu hubungan konflik menemukan penyelesaian. Beberapa konflik yang telah dirangkum dalam tabel diatas telah diselesaikan dengan adanya intervention dari pihak-pihak seperti DKPP dan KIP Provinsi Aceh.

Menentukan Outcome (hasil akhir) yaitu dampak dari berbagai tindakan pihak-pihak berkonflik dalam bentuk situasi. Konflik dan pelanggaran pemilu yang terjadi di Aceh Tenggara akan berdampak kepada defisit demokrasi. Sanford Levinson [15]; menggambarkannya sebagai kondisi dimana organisasi dan lembaga demokrasi tidak mampu memenuhi prinsip-prinsip demokrasi dalam menjalankan tugasnya. Pemilu dengan intensitas kecurangan dan konflik yang tinggi tentu tidak akan menghasilkan pemimpin yang berkualitas karena pilihan politik yang diberikan masyarakat tidak lagi berdasarkan rasionalitas.

\section{Kesimpulan dan saran}

Pemetaan konflik model SIPABIO diatas memberikan kesimpulan bahwa Aceh Tenggara merupakan daerah yang menyimpan potensi konflik. Meskipun intensitasnya menurun dari setiap pelaksanaan pemilu, konflik yang terjadi tetap perlu diwaspadai. Analisis pemetaan Konflik model SIPABIO menunjukkan bahwa terdapat tiga pihak utama yang menjadi sumber konflik yaitu KIP Aceh Tenggara, Kepolisian, dan simpatisan masing-masing calon. Ketiganya dominan menunjukkan sikap noncoercive action dengan melakukan intimidasi, money politic, dan demonstrasi. Dalam hal ini, intervensi pihak ketiga seperti DKPP dan KIP Provinsi Aceh sejauh ini berhasil meredam konflik tersebut.

Berdasarkan penelitian ini, tim peneliti memberikan rekomendasi berupa pengawalan dan pencegahan konflik yang harus dilakukan oleh simpatisan dan kandidat, penyelenggara pemilu khususnya KIP, dan kepolisian. Komitmen kuat para simpatisan dan kandidat diperlukan untuk menjaga perdamaian dan keamanan penyelenggaraan pemilu. Keduanya harus bersinergi dalam membangun hubungan positif dan tidak melakukan tindakan provokasi yang menimbulkan prejudice. Penyelenggara pemilu khususnya KIP Aceh Tenggara hendaknya melaksanakan tugas secara baik dengan mengedepankan konsep fairness system dan independen. Sama hal nya dengan penyelenggara pemilu, kepolisian harus memainkan peran penting dalam melakukan pengawalan dan mereduksi konflik. Segala macam bentuk keberpihakan harus dihilangkan demi mewujudkan pemilu yang adil. 


\section{Ucapan Terima Kasih}

Penelitian ini merupakan salah satu keluaran Laboratorium Ilmu Politik (LIP), Fisip Unsyiah. Melalui pengajuan proposal penelitian, LIP mendapat kesempatan untuk mendapatkan dana hibah laboratorium yang diberikan oleh LAB Terpadu Unsyiah. Sebelumnya, LIP telah mendapatkan hibah yang sama untuk melakukan penelitian pemetaan potensi konflik di Kota Sabang. Hasil dari penelitian tersebut telah kami presentasikan dalam International Conference on Islam and Local Wisdom di Kendari pada 25-26 April 2017. Penelitian ini merupakan penelitian lajutan dengan harapan LIP nantinya akan memiliki data pemetaan konflik pemilu bagi daerah seluruh Aceh. Atas terselenggaranya penelitian ini, tim peneliti mengucapkan terimakasih yang sebesar-besarnya atas bantuan dana yang telah diberikan oleh LAB terpadu Unsyiah.

\section{References}

[1] F Kontras. 2014. Laporan Serangkaian Keerasan dan Penembakan di Aceh menjelang Pemilu 2014 di Provinsi Aceh.

[2] World Bank. 2007a. Laporan Pemantauan Konflik di Aceh 1-3 Agustus 2007. Decentralization Support Faciliy, Conflict and Development.

[3] Perludem. 2014. Potensi kekerasan dan Pelanggaran Pemilu di Aceh. Perkumpulan Untuk Pemilu dan Demokrasi (perludem). SiaranPers.

[4] Clark and Palmer

[5] Abdalla,A., et al. 2002. Understanding C.R. SIPABIO: A Conflict Analysis Model. Di dalamSay Peace: Conflict Resolution Training Manual for Muslim Communities. Virginia, USA: The Graduate School of Islamic and Social Sciences: 44-51.

[6] Koran Tempo. 6 Maret 2014. Aceh Utara Paling Rawan.

[7] Rakyat Aceh. 4 Januari 2007. Dewan Dan Camat Dilaporkan Warga Ke Panwaslih.

[8] World Bank and UNDP. 2006. Laporan Dinamika Pilkada Aceh - Edisi Pertama.

[9] World Bank. 2007b. Laporan Pemantauan Konflik di Aceh September 2007. Decentralization Support Faciliy, Conflict and Development.

[10] World Bank. 2007c. Laporan Pemantauan Konflik di Aceh Oktober 2007. Decentralization Support Faciliy, Conflict and Development.

[11] World Bank. 2009. Laporan Pemantauan Konflik di Aceh 1 Desember 2008- 28Februari 2009. Decentralization Support Faciliy, Conflict and Development.

[12] DKPP 2012, putusan No.04/KE DKPP/VII/2012http://www.rumahpemilu.com/public/doc/2012_10_10_12_36_20_PUTUSAN_NOMOR _04KE-DKPPVIII2012.pdf. Diakses pada 20 September 2017.

[13] AJNN. 2014. Riefky Minta Dugaan Pelanggaran Pemilu Di Aceh Diusut. https://www.ajnn.net/news/riefky-minta-dugaan-pelanggaranpemilu-di-aceh-diusut/index.html.Diakses pada 18 September 2017

[14] Serambi TV. 2016. Ribuan Pendukung Paslon Raidin-Bukhari Demo Kantor KIP Agara.

[15] Levinson, Sanford. 2007. How the United States Contribute to the democratic deficit in America. Drake Law Review Volume 55, Number 4, Summer 2007. 